\title{
The Repluralization of Czechoslovak Politics in the 1960s
}

Czechoslovakia has undergone revolutionary changes in its political and institutional structure several times in the twentieth century. In 1918 the leaders of the Czechs and Slovaks decided to sever their political umbilical cords to Vienna and Budapest, giving birth to the Czechoslovak Republic, a democratic state that differed considerably from the Austro-Hungarian Empire from which it had emerged. In 1938 this democracy gave way to a semiauthoritarian regime, the so-called Second Republic. The Second Republic existed for a few months at Hitler's sufferance, only to be divided into two parts, both controlled by the Third Reich from 1939 to 1945 . In 1948, after a three-year attempt to harmonize Communist and non-Communist parties in a left-leaning National Front government, Czechoslovakia became for twenty years an autocratic Communist state. During these two decades the methods of rule varied from totalitarian (1948-53) to what might be called moderately authoritarian (1963-67). In 1968 , with the advent of a new leadership committed to sweeping economic and sociopolitical reform, Czechoslovakia was on the threshold of still another revolution, only to be frustrated and forced backward in its political development by the invasion of its own allies in August. ${ }^{1}$ It is obvious that drastic political change has been a recurrent theme in the twentieth-century history of this small Central European country.

Under the surface of this turbulent political history, however, there are a number of remarkable continuities that have given Czechoslovak society a certain stability. ${ }^{2}$ The tendency among scholars has been to emphasize those characteristics of Czechoslovak politics that exaggerate the distinctiveness of

1. Numerous studies of the 1968 events have been published, among them Galia Golan, Reform Rule in Caechoslovakia (Cambridge and New York, 1973); Vladimir V. Kusin, Political Grouping in the Czechoslovak Reform Movement (London and New York, 1972); and Ivan Sviták, The Czechoslovak Experiment, 1968-1969 (New York and London, 1971). See also Robin Alison Remington, ed., Winter in Prague: Documents on Csechoslovak Communism in Crisis (Cambridge, Mass., 1969), and I. William Zartman, ed., Czechoslovakia: Intervention and Impact (New York and London, 1970).

2. David W. Paul, "Nationalism, Pluralism, and Schweikism in Czechoslovakia's Political Culture" (Ph.D. diss., Princeton University, 1973).

I am indebted to my colleagues Peter Sugar and Ruth Horowitz for their thoughtful comments on an early draft of this article. 
each historical period and obscure the underlying continuities. ${ }^{3}$ Because of this approach, the image we have of Czechoslovakia is that of a little country, oscillating during its history between extreme repression and hopeful experimentation, depending upon the personalities of those in control and upon the hegemonial policies of the larger nations immediately beyond the borders.

Happily, we have begun to witness the revision of this interpretation, slowly in the 1960s and more rapidly and convincingly in the years since the experiment of $1968 .^{4} \mathrm{It}$ is now apparent that the reforms of 1968 sprang from numerous undercurrents of change already in motion, both within the party and outside it, for nearly a decade. It has even been suggested that this entire movement had its roots in national traditions traceable throughout the long history of Bohemia. ${ }^{5}$ Nevertheless, a clear and definitive explanation of the macrohistorical forces behind the events of the sixties, by and large, eludes us. Because of this, some confusion surrounding the course of the reform movement still exists.

It is the purpose of this article to offer a preliminary interpretation of one major change during the 1960s: the re-emergence of political pluralism. The Czechoslovak reform movement did not take place-to use a well-worn cliché-in a vacuum. The Prague Spring of 1968 was not a sudden anomaly, nor was it a nationalistic revolt against foreign domination (although there were elements of nationalism involved, both Czech and Slovak). Rather, the Prague Spring was the culmination of a gradual reform process that began in response to widely felt alienation from the political system, a feeling that the system represented a fundamental violation of profound national values. The process entailed a protracted self-examination on the part of Czechs and Slovaks, in the course of which they rediscovered their past and sought to define their present and future in terms of that past. ${ }^{6}$ During this self-examination

3. See, for example, Edward Taborsky, Communism in Czechoslovakia, 1948-1960 (Princeton, 1961) ; Zdenek Suda, The Cacchoslozak Socialist Republic (Baltimore, 1969); and Barbara Wolfe Jancar, Czechoslovakia and the Absolute Monopoly of Pozver: $A$ Study of Political Pozer in a Communist Sy'stem (New York, 1971).

4. Edward Taborsky, "Change in Czechoslovakia," Current History, 48, no. 283 (March 1965) : 168-74; H. Gordon Skilling, "Communism and Czechoslovak National Traditions," Journal of Intcrnational Affairs, 20, no. 1 (1966) : 118-36; Morton Schwartz, "Czechoslovakia: Toward One-Party Pluralism?" Problems of Communisn, 16, no. 1 (January-February 1967): 21-27; Galia Golan, The Czechoslovak Reform Moventent (Cambridge, 1971); Vladimir V. Kusin, The Intellectual Origins of the Prague Spring (New York and Cambridge, 1971); and Jaroslav Krejči, Social Change and Stratification in Postwar Czechoslovakia (London and New York, 1972).

5. A. H. Brown, "Political Change in Czechoslovakia," Govermment and Opposition, 4, no. 2 (Spring 1969): esp. pp. 189-94.

6. The Prague Spring is, of course, a misnomer, and the author apologizes for resorting to this popular but inaccurate abbreviation. In the first place, it was not just Prague that was affected by the 1968 changes but the entire country, Czech and Slovak, 
a vital component of the political culture was uncovered: the natural and intrinsic pluralism of Czechoslovak society. ${ }^{7}$

Political pluralism, with which we are concerned here, can be defined in two ways. In the first sense, pluralism has to do with the relation between the social structure of a given community and the community's patterns of political behavior. A pluralistic society, therefore, is one composed of identifiable, differentiated strata giving rise to corresponding differentiations in the political behavior of citizens. Pluralism, it should be stressed, is not identical with social differentiation. Rather, it includes such differentiation as a precondition to diverse political behavior patterns. In the second sense, pluralism concerns the distribution of political power. A pluralistic society thus defined is one in which there are actively competing forces in the political system-parties or other organized (or somewhat organized) groupings capable of sharing in, or challenging, the established power structure. Both of these definitions are applicable to the Czechoslovakia of 1968, and both emerged from phenomena well known in the nation's earlier history.

Pluralism among the Czechs and Slovaks has reached a high degree of development during several different time periods, and it has exhibited characteristics suggesting that it is deeply embedded in the political culture. Like all attributes of a political culture, pluralism in Czechoslovakia is normative, observable, durable, and labile. It is normative in the sense that the average citizen feels a need to identify with an organization that expresses his political interests and orientations; he feels it natural that individuals perceive politics in different ways, and he finds it similarly natural that the political system allow for these divergent perceptions by providing an adequate institutional

urban and rural; and the political events taking place reflected in a complex pattern the local differences of Czechoslovakia. In the second place, the "Spring" of reform actually began in January and lasted until some months after the August intervention, passing through several quite distinct stages.

7. Political culture has been defined and discussed elsewhere, both by the present author and by others. See Paul, "Nationalism, Pluralism, and Schweikism"; also Gabriel A. Almond, "Comparative Political Systems," Joumal of Politics, 18 (August 1956): 391409; Gabriel A. Almond and Sidney Verba, The Civic Culture (Princeton, 1963) ; Lucian W. Pye and Sidney Verba, Political Culture and Political Development (Princeton, 1965); and Richard R. Fagen, The Transformation of Political Culture in Cuba (Stanford, 1969). As used here, the term "political culture" refers to a certain observable configuration of values, orientations, and behavior patterns related to the politics of a society. A political culture, so defined, is not completely static, although there is an inherent quality of inertia. Changes in the political culture will generally occur either very gradually or in the context of circumstances involving a sudden, and usually violent, break with the past. A political culture can absorb gradual, incremental changes-hence it is relatively labile. But sudden, large-scale changes will invariably encounter great obstacles, for such changes involve an upheaval in value patterns that are usually deeply rooted. This kind of change is, of course, the nature of a revolution-a violent rupture of traditional norms and practices. 
framework for the aggregation of political interests. This was, in fact, the nature of the interwar party system. Notwithstanding its many shortcomings, that system represented a rather effective mechanism for aggregating the most diverse political orientations. ${ }^{8}$

Pluralism is observable recurrently in Czechoslovakia's political history. Political movements pluralized in Bohemia and Moravia during the last few decades of the nineteenth century, especially in the 1890s, and in Slovakia during the first decade of the twentieth century. In the Austrian general elections of 1907 at least ten Czech parties ran candidates and received significant numbers of votes on the basis of their social and national appeal. Even among the Slovaks, politically repressed though they were in the Hungarian half of the Habsburg Empire, three significant parties functioned by 1914, and there were numerous additional semiorganized political movements. ${ }^{9}$ During the interwar years, pluralism of political parties reached an extreme, encouraged by the proportional representation guaranteed by the First Republic constitution. No fewer than twenty-three parties gained parliamentary representation at one time or another between 1918 and 1938, and there were also a number of smaller splinter parties, mostly of an ephemeral nature. These were based on a bewildering configuration of ethnic, class, and religious identity patterns, but within and among these social groupings were many subgroups and a great deal of overlapping. In other words, nationality, socioeconomic class, and religious affiliation were important determinants of political party identification, but one could not draw totally firm correlation's between, for example, Catholic voters and clerical parties, or between working-class voters and one or another socialist party. Parties had overlapping constituencies, and social groupings were ordinarily fragmented in their party loyalties. In short, the stratificational basis of party politics was indistinct. ${ }^{10}$

The durability of pluralism in Czechoslovakia can be seen in the fact that

8. Some observers of interwar Czechoslovak politics have faulted the system for having been excessively pluralistic and participatory. Milan E. Hapala, for example, has argued that the Czechs' attraction to politics "led to an overvaluation of all that was political. The citizen became too deeply involved in politics, his political partisanship taking precedence over other values." Because of the multiplicity of minority parties drawn together into coalition cabinets, "the programs advocated by the parties, and chosen by the voters were modified and, at times, nullified by the need for compromise." Milan E. Hapala, "Political Parties in Czechoslovakia, 1918-1938," in Miloslav Rechcígl, Jr., ed., Czechoslovakia: Past and Present, 2 vols. (The Hague and Paris, 1968), 1:138-39.

9. Robert A. Kann, The Habsburg Empire: A Study in Integration and Disintegration (New York, 1957), pp. 375-79; Karel Capek, President Masaryk Tells His Own Story (New York, 1935), p. 193.

10. Beneš felt that the overlapping constituencies of the parties made coalition politics easier and less conflict-ridden than in other European democracies. See Edžard Benešs in His Own Words, comp. K. Hudec (New York: Czech-American National Alliance, 1944), p. 27. 
society repluralized in the mid-1940s and again in the 1960s, despite the disruption and rearrangement of the traditional social base by the German occupational regime and the Slovak satellite government (1939-45) and the leveling, totalitarian regime of the Gottwald-Novotny era. Both of these periods reflected circumstances of foreign-imposed politics. Although it is true that both the Nazis and the Soviets found considerable numbers of willing collaborators among the Czechs and Slovaks, the political systems that emerged under foreign constraints represented the proclivities of a decided minority. ${ }^{11}$ Pluralism as an active and concrete phenomenon was repressed during these times; parties and interest groups were disbanded or co-opted into the official system, and politics was forcibly made into a narrow, ideologically exclusive domain. The passive, "Schweikian" tendencies of most Czechs and Slovaks rendered them vulnerable to the zealotry of the collaborating extremists. ${ }^{12}$ Where passivity did give way to active opposition, raw force was used to maintain monolithic order. This is not to say that the pluralist orientations of Czechs and Slovaks were destroyed. Rather, they were submerged, unable to find articulation, and eventually released upon the demise of the antipluralistic regimes in 1945 and 1968. In each case, the "new" pluralism that emerged was muted compared with that of the First Republic, restrained by governmental policy and external threat, but nonetheless genuine and vibrant.

Finally, the lability of Czechoslovak pluralism is evident in the entirely new pattern of pluralization following the socialist revolution from 1945 on. ${ }^{13}$ The pluralism that eventually came forth in the sixties reflected a social base

11. Even though the Communists polled a plurality of the votes $(38.1$ percent $)$ in the 1946 parliamentary elections, this vote cannot realistically be interpreted as a mandate for the totalitarian policies of the post-1948 years. Many voters chose the Communists because they offered the most radical social reform programs, including the vengeful promise of redistribution of German properties. Some others apparently voted Communist for reasons only indirectly related to specific policies-for example, the Communists' muchadmired record of wartime resistance to the Nazis and their local collaborators. Many Communist voters became disillusioned after 1946 because of the party's obstreperous governmental tactics within the Third Republic coalition. By January 1948 there was evidence that the Communists were losing the plurality of support that they had won in 1946 .

12. By "Schweikian" tendencies I mean passive or nonviolent patterns of behavioral response to crisis, as symbolized by the adventures of Jaroslav Hašek's fictional character the Good Soldier Schweik, in the famous post-World War I novel of that name. "Schweikism" can include both compliance and resistance on the part of individuals vis-à-vis an oppressive system, but the outward behavioral passivity typically masks a deep-seated and profound inner rejection of the alien system. See Paul, "Nationalism, Pluralism, and Schweikism," pp. 253-300.

13. Although the 1948 Communist coup was the necessary prerequisite to the most radical changes in social policies, the basic socialist course was set in the immediate postwar period with the nationalization of large industry and a sweeping land reform. The latter program was, of course, abandoned later in favor of collectivization. 
very different from that of earlier periods. The new political groupings were not based on religious or class identification, and although nationality was an important factor (as it had been before 1945), it was only one of several. Much of the new pluralism was the product of social stratificational patterns that specifically grew out of the post-1945 socialist order. That order itself resulted from the social revolution of the early postwar years, a revolution that had a self-conscious class-leveling effect throughout Czechoslovakia. ${ }^{14}$ Therefore, although it is important to stress the normative roots of the new pluralism in the earlier, "bourgeois," era, it is also necessary to remember that the form pluralism took in the 1960s was not the same as that of the First (1918-38) and Third (1945-48) Republics. It is thus appropriate to refer to this phenomenon as a "repluralization," both in the sense that the general process had taken place at a previous time, and in the sense that there was something novel about it.

\section{New Patterns of Pluralism}

The repluralization of the sixties actually occurred in two waves. The elite strata divided during the early and mid-1960s; the nonelites, for the most part, not until 1968.

Various reform factions developed in the Communist Party early in the decade, some of them perhaps reaching back into the late fifties. By 1967 the dominant Novotný wing-conservative, anti-Slovak, and tied by implication to the judicial atrocities of the early fifties-found itself confronted by a number of actual or incipient groups developing in competition with the rulers: a Slovak nationalist wing, including persons of such differing political outlooks as Dubček, Husák, and Bil'ak; a group that we might call the "liberal-technocratic" faction, consisting of economic experts and others favoring increased marketization and profitability aspects in the economic system, including Ota Šik, Evžen Loebl, and Radovan Richta; and a cultural libertarian wing that included the majority of writers and artists, concerned with the relaxation of social and cultural constraints. In addition, there were many party members who did not exactly fit into identifiable groupings but made their opposition to the government's policies known. These included party reformer Zdeněk Mlynáŕ, legal scholar Michal Lakatoš, and some scattered left-wing Marxists with antibureaucratic and even antiauthoritarian sympathies. The Novotný clique managed to hold power, maneuvering among these hostile but splintered groups, until the end of 1967. At that time an ad hoc coalition formed at the

14. See Pavel Machonin et al., Ceskoslovenská společnost [Czechoslovak Society] (Prague, 1969), and Krejčí, Social Change and Stratification. 
top level of the party hierarchy and toppled the old regime, electing a new leadership and creating the momentum that led to the Prague Spring.

Dubček was the symbolic head of the leadership group, but he was by no means supreme, and the course of the government's discussions in 1968 indicated considerable disunity regarding the methods of carrying out what was now called the "democratization" of Czechoslovak society. As these discussions proceeded, the party came to share power with other institutions such as the National Assembly, the Cabinet, and the trade unions. Important as these divisions of power were, the re-emergence of pluralism did not stop here. It spread to the masses-carried to them by an increasingly open press-and reawakened society's political impulses. The party and government, of course, attempted to remain in the forefront of the reform movement, but events moved rather quickly beyond their capacity to control them. For now, the process of repluralization had drawn large numbers of private citizens into political activism.

Ivan Sviták, a Marxist philosopher, has described the "Czechoslovak experiment" of 1968 as a phenomenon that consisted, in his words, of "several democratization movements ... other than the one that operated under the leadership of the Communist Party." These reflected a spectrum of political and ideological groupings "ranging from Maoists to veterans of the Czechoslovak Legion who had fought the Russians during World War I."15 These are obviously extreme examples representing very minor groups, but Sviták's point is that many political orientations came to be reflected in the moods of the public. Repluralization had proceeded gradually among the elites before 1968 , but now it spread rapidly on all levels of society. It seemed that once the movement got going, everybody became politicized, and institutional groupings were formed to accommodate them. New organizations sprang up overnight, attracting sizable followings. Old institutions long moribund suddenly awoke and assumed a new life. And everywhere public discussion of political issues took place-in the pubs, on the streets, in living rooms, on the streetcars, in the newspapers, and at the meetings of groups such as KAN. ${ }^{16}$ By the middle of summer, the possibility of a genuine multiparty systemincluding a revivification of the puppet Socialist and People's Parties and the renascence of the Social Democrats-had become a matter of serious public discussion. The Communist leadership was resisting the pressures by the

15. Sviták, The Czechoslovak Experiment, p. 4.

16. KAN, the Club of Committed Nonpartisans (Klub Angažovaných Nestranikü), was a loose network of local clubs formed for the purpose of discussing politics and seeking to influence legislation. Many of KAN's more prominent members were assumed to have personal political ambitions, although KAN itself was never advanced as an opposition party. In the course of 1968 the most important function of KAN was as an active but as yet relatively weak lobby for democratic and humanitarian causes. 
would-be political groups, but it is doubtful that the party could have resisted indefinitely without resorting to coercion, a most disagreeable prospect that was ultimately made a reality by the August invaders.

Vital to the repluralization of society was the role of the mass media. The media became a catalyst of public activism, transmitting news of the government's progress and urging the masses to become involved in the great events of the day. Reporters tore open a number of wounds that had been festering for a long time, and almost nothing was beyond the bounds of their inquiry. The political trials of the fifties, foreign policy, the mysterious death of Jan Masaryk in 1948, probing interviews with party and government leaders-all these were explored in depth by newspapers from Rudé právo to small organs of the provincial press. Foreign journalists, astounded at what they read in the newspapers, declared that Czechoslovakia enjoyed the "freest press in the world," uncensored by the state and unbeholden to commercial sponsors. ${ }^{17}$ The role of communications in the events of 1968 should not be underestimated. Press and other media contributed immensely to the public's awareness of what was happening and, in turn, encouraged the masses to use every opportunity to join the participatory movement.

Another instrument of repluralization was the nation's youth, especially students in universities and technical institutes. Although most young people had been apolitical during the earlier 1960s, some had undergone a gradual politicization. Following the infamous episode at the Strahov hostel in the fall of 1967 , larger numbers of students got involved. ${ }^{18}$ They warmed quickly to Dubček and the post-January policies, and whereas the masses in general were more hesitant to respond to the new circumstances, many students became political activists early in 1968. For the most part, they remained outside the party during this early stage. Nonetheless they formed a sort of bridge between the party and the workers, keeping the latter in touch with all the new developments and urging them to give Dubček their support.

In the spring and summer young people made their own contribution directly to the repluralization of institutions. The old transmission-belt institution, the Czechoslovak Union of Youth (CSM), splintered. At least ten

17. "Svoboda"-Die Presse in der Tschechoslowakei, 1968 (Zurich: Internationales Presseinstitut, 1969), pp. 35-36 and passim.

18. On October 31 some Prague students were arrested for publicly protesting a power cut-off in their hostel. Further demonstrations ensued in protest against the arrests, and the police responded with beatings and more arrests. The demands of the students now escalated to include academic and political freedom. The Novotný government at first condemned the students, then criticized the police, and finally, after more than a nonth had passed, released the incarcerated demonstrators. A general wave of indignation swept through Prague in response to this incident, and many influential party members shared in the censure of the regime. It is very likely that the Strahov hostel incident thus contributed to the timing of Novotny's downfall, which occurred within a month of the students' release. 
separate organizations sprang up in its place, each new group representing a distinct regional or promotional interest. Later, almost a month after the occupation, a journalist for the newspaper Mladá fronta (Youth Front) was to make a curious dialectical argument to the effect that the pluralization of the youth movement actually served to unify it, since the "new political reality of socialist Czechoslovakia" demanded a plurality of young people's organizations to answer the diverse needs of their generation. ${ }^{19}$

Adult organizations underwent a comparable revitalization. The Revolutionary Trade Union Movement ( $\mathrm{ROH}$ ) had a change of leadership at the top and adopted new statutes; non-Communists moved into some influential positions in many factory-level units, and the $\mathrm{ROH}$ took on a new look as a relatively looser umbrellalike organization overlying reinvigorated local unions. Old professional associations-the Union of Czechoslovak Lawyers, the Czechoslovak Medical Society, the Architects' Union, and others-functioned once again. Unique new organizations arose, such as the highly politicized KAN and the remarkable Club 231, the latter an association of former political prisoners convicted during the fifties under the notorious Law No. 231 (Law for the Defense of the Republic). ${ }^{20}$ In short, voluntary organizations sprang up everywhere. Ultimately these groups became incipient vehicles of political articulation, seeking to represent their constituents' political interests and exerting pressure on the government for this purpose.

This repluralization was by no means completed by the time it was interrupted in August. In fact, the mood of the public during the summer was so volatile that it was quite impossible to guess what directions it might take from one day to the next. The threat to the Communist Party's authority was a real issue-it was not just a story manufactured by the Soviets and their allies to excuse their intervention. In many respects the political initiative had passed from the party to the masses. The people were out in front of the party, constantly putting pressure on Dubček and others to move in one new direction or another. The masses and their diffuse spokesmen were openly challenging the Communists' hitherto exclusive right to make policy. What had started as a controlled program of reform-from-above had exploded into a democratic, or at least democratizing, mass movement which threatened the bases of the party's rule.

\section{Pluralism in Caechoslovakia: A Theory}

A number of circumstances in the history of the Czechs and Slovaks predisposed their societies to democracy and pluralism. The most important was

19. Zbyněk Vokrouhlický, "Jednota v pluralitě," Mladá Fronta, Sept. 17, 1968.

20. A moving account of Club 231 activities is given in the autobiography of one of the club's founders, Jaroslav Brodský, Solution Gamma (Toronto, 1971). 
the absence, since the seventeenth century, of a national nobility. The Bohemian aristocracy had been thoroughly decimated following Bohemia's defeat by Habsburg forces in the first phase of the Thirty Years' War. The Slovaks, because of their thousand-year subjugation to Hungary, never developed a native aristocracy. In both Bohemia-Moravia and Slovakia all economic and social privileges were in alien hands throughout the eighteenth and most of the nineteenth centuries, a critical time in the evolution of the national cultures. Czechs and Slovaks were at the bottom of their respective social orders, and therefore politically equal among themselves. With the coming of the industrial revolution to Bohemia and Moravia, a Czech bourgeoisie and a working class arose, giving the social structure a new flavor of heterogeneity. From the ranks of the bourgeoisie came most of the national political leaders of the late Habsburg years, but their basis of popular support was necessarily and self-consciously drawn from the broadest possible segment of the public.

The national revivals, then, were propelled by a wide-ranging portion of a relatively equalitarian population. This was especially true of the Czechs: workers and peasants, clergymen and shopkeepers, businessmen, professors, lawyers, artisans, and writers all were drawn into the renascence. ${ }^{21}$ When it reached a decidedly political phase in the last three decades of the century, the nationalist movement encountered the effects of modernization in the AustroHungarian Empire. Because the national revivals now dovetailed with the ongoing social revolution in all its dynamic aspects-industrialization, urbanization, secularization, and increasing socioeconomic mobility-the democratically based political movement of nationalism took on varied meanings to people of different localities and occupational groupings, at diverse levels of education and sophistication. The result was still a general feeling of national unity on what we might call the macro-level of society, but increasing differentiation of political and ideological outlooks on the micro-level-that is, the individual level. This gave rise to the formation of multiple parties around the interests of the various groupings.

The multiparty system became the embodiment of the pluralism that characterized Czech and Slovak politics from 1890 to the collapse of the First Republic. It was encouraged by the liberal atmosphere of the post-1918 state, whose constitution, meticulously borne out in practice, allowed for parliamentary representation of the parties proportional to their vote tallies. This system, of course, had its problems and limitations. ${ }^{22}$ But within this general environ-

21. See, for example, J. Butvin and J. Havránek, Dějiny Ceskoslovenska, vol. 3 (Prague, 1968), pp. 14-279; S. Harrison Thomson, Czechoslovakia in European History (Princeton, 1943); and Peter Brock and H. Gordon Skilling, eds., The Czech Renascence of the Ninetcenth Century (Toronto, 1970).

22. Among these shortcomings was the inevitable necessity of compromise in order to achieve coherent governmental policies. See note 8 above. 
ment the normative assumption of political pluralism grew and flourished, and it became an integral part of the Czechoslovak political culture. The factors that originally gave rise to pluralist orientations - class and religion in particular-tended to recede into the background, and partisan politics became a way of life.

It was not only party politics that reflected Czechoslovak pluralism. From the late nineteenth century, Czech society had developed a strong tradition of interest-group politics, and this tradition underlay much of the country's pluralism. During the late Habsburg period, voluntary organizations formed for cultural, economic, and athletic purposes frequently took on political tones, engendering in their members a sense of national patriotism and self-identification. With good reason, it has often been suggested that the voluntary-cumpolitical group tradition was a vital factor in creating a deeply rooted political culture of democracy and pluralism. From the gymnastic Sokol clubs to the trade unions, and from choral societies to rural cooperatives, pre-1948 Czechoslovakia was characterized by a multiplicity of voluntary organizations, each one contributing to the color and variety of social experiences. ${ }^{23}$

The economic and social revolution following the Second World War produced a superficial homogenization of society. In economic terms society was leveled by the policies of the postwar government, especially the nationalization of industry, land reform, and collectivization, and a series of draconian monetary and price reforms that wiped out personal savings and discriminated savagely against the middle and upper strata. In contrast to the Stalinist revolution in the USSR during the thirties, where one of the costs of rapid industrialization was gross inequality in income distribution and social prestige, Czechoslovakia's revolution had the opposite effect. Wages and salaries became significantly less differentiated, social security and national health insurance were made universal, educational opportunities were expanded for those who previously had little or no access to them, and, importantly, there occurred a gradual but marked tendency toward greater equalization between the Czech and Slovak economies. ${ }^{24}$

But this is not to say that society was not stratified, as a team of Czech and Slovak sociologists led by Pavel Machonin discovered in the sixties. ${ }^{25}$ The

23. See Václav Beneš, "Background of Czechoslovak Democracy," in Miloslav Rechcígl, Jr., ed., The Czechoslovak Contribution to World Culture (The Hague, 1964), pp. 267-76.

24. Krejči, Social Change and Stratification, pp. 27-62; also Otto Ulc, "The Impact of Modernization on Political Development in Czechoslovakia," paper presented to the conference on Eastern Europe, "The Impact of Modernization on Political Development," Columbia University (March 23-24, 1973). It should be noted that Czechoslovakia was already a relatively egalitarian country, even during the "bourgeois" period. Income differentiation, especially in the Czech lands, was relatively low.

25. Machonin, Ceskoslovenská společnost. This remarkable book, published before the reimposition of censorship in 1969, is no longer in print, and consequently copies of 
previously existing class structure had in fact been eliminated by the postwar revolution. Although that structure had been characterized by rather indistinct social cleavages and a relatively low degree of class self-identification, the removal of distinctions among proletariat, bourgeoisie, and peasantry meant the elimination at the same time of the weak (but nonetheless real) class basis of pre-1938 pluralism. Moreover, the heavy-handed tactics used by the state against the churches after 1948 completely secularized politics and removed the religious basis of political differentiation. Yet, notwithstanding the virtual disappearance of classes in the traditional sense, Czechoslovak society came to be restratified both horizontally and vertically. ${ }^{26}$

Horizontally, social groupings emerged around a pattern of differentiation based on occupational and other spectra deriving from the specialized and sophisticated nature of modern society. Social stratification in this "horizontal" sense thus revolves around what the Czechoslovak sociologists call a "bundle" of sociocultural factors-type and complexity of work performed, style of life and leisure, geographic locale, ethnic identity, biological considerations (sex, for example), and level of spiritual life. The sociologists recognized these factors as important determinants of the individual's sense of identity and hypothesized, further, that the evolving social groups had objectively different self-interests.

It is not surprising, actually, that these factors should be of such significance. It seems only natural that a medical doctor, for example, would have interests and personal habits different from those of a latheworker, or that the world view of a highly educated urbanite would be different from that of a partially educated peasant. To the Marxist sociologists in Prague and Bratislava, however, this was a remarkable discovery, for it contravened the assumption of traditional Marxism-Leninism that socialism must bring about decreasing social differentiation. ${ }^{27}$ The Czechoslovak sociologists argued that this complex pattern of socialist stratification gives rise to differentiated po-

it are hard to find. Two preliminary efforts, both edited by Machonin, are somewhat more


$v$ sociälní struktuře Ceskoslovenska a dynamika sociálnè-politického vývoje (Prague, 1967). For an excellent review of the 1969 volume see Ernest Gellner, "The Pluralist Anti-Levellers of Prague," Government and Opposition, 7, no. 1 (Winter 1972): 20-37.

26. Machonin refers only to the vertical pattern as "stratification" and calls the second pattern simply "horizontal differentiation." I see no reason, however, to make this distinction, since the groupings that Machonin describes are characterized by features suggestive of social strata in the conventional sense; that is, they are distinguished by the relative social positions, educational levels, attitudes, and habits of their members.

27. Some Yugoslav social scientists, for example, argue that even though social differentiation exists today, the tendency is toward its eventual elimination or diminution. Cf. Branko Horvat, An Essay on Yugoslav Socicty (White Plains, N.Y., 1969), pp. 145-76. 
litical interests among the working-class masses. Not only do the new social strata appear as superficially differentiated groupings with variable tastes and predilections, but they even think differently. This means that they have perceived identifiable, stratum-specific interests. ${ }^{28}$

At this point the sociologists were talking primarily about latent interests, for before 1968 these interests could not be clearly identified; rather, they could only be hypothesized. In fact, we might best refer to the groupings emerging before 1968 as "quasi-groups" rather than "interest groups," because their interests were largely latent and unarticulated. ${ }^{29}$ It took the events of the Prague Spring to crystallize the forces involved and bring the interests out into the open.

"Vertical" differentiation reflects a simpler and less subtle division, one with which the Machonin group of sociologists did not successfully come to grips. They attempted to describe a vague pattern of status-ranking according to considerations stich as division of labor and basic position in the productive process, but they failed to come to terms with the most important criterion, a factor that Machonin euphemistically calls "participation in the organization and planning of society." ${ }^{30}$ No doubt the sociologists recognized the importance of this factor but felt constrained from dealing with it in detail because of the political-power implications. Yet it is a vitally important matter and deserves our attention. ${ }^{31}$

What Machonin calls "participation in the organization and planning of society" is, in a more succinct term, politics. Political power in Czechoslovakia, as in all highly authoritarian systems, is the exclusive province of a ruling elite. With respect to power, society is sharply divided into two main components according to access to, and share in, economic and political authority ${ }^{32}$

28. Z. Mlynář and V. Pavlíček, "Politická organizace ve vztahu $\mathbf{k}$ vývoji sociální struktury socialistické společnosti" [The Relationship Between Political Organization and the Social Structure of Society], in Machonin, Sociálni struktura, pp. 642-59.

29. See Morris Ginsberg, Sociology (London, 1934), pp. 40-41, for the earliest use of the term "quasi-groups."

30. Machonin, "K obecnému vymezení pojmu 'sociální struktura," in Sociálni struktura, pp. 15-43 (quotation on p. 28).

31. Cf. Krejčís discussion of this relationship, which he calls "position within the power structure" (Social Change and Stratification, pp. 105-30).

32. This is a vertical pattern much starker and more power-related than those frequently used to describe Yugoslav and Polish societies. In the latter cases, vertical stratification reflects commonly perceived rankings of people in terms of social prestige; there are numerous gradations within the vertical scale, with political leaders at the top, peasants normally at the bottom, and several other occupational groups in between. See Horvat, Essay on Yugoslav Society, pp. 145-76, and Jan Szczepański, Polish Society (New York, 1970), pp. 105-46. Czechs and Slovaks, too, see themselves in terms of social status (prestige) but seem also to recognize the more fundamental power differentiation as something far more significant. 
Regardless of one's occupation, level of education, or even income, an individual who is not a nember of the economic-political elite is distinctly apart from one who is, because the former has no influence whatsoever on the political decision-making process. In pre-1968 (as in post-1968) Czechoslovakia there was a clear and omnipresent barrier dividing those who had power, actually and potentially, from those who did not. This barrier also divided the many from the ferv. The many are those outside the ranks of the elite-powerless, incapable of affecting the political system, relatively equal among themselves but relatively impoverished in comparison with those on the other side of the barrier. The few are the elites: party leaders, bureaucrats, high-level military officers, trade union officials, police, economic planners, and managers. ${ }^{33}$ The elites live in their own world, removed from the masses, almost totally out of touch with them except to the extent that they can enforce demands upon them, usually through a chain of subordinates. (In some cases, even this kind of contact between the elites and the masses came to be weakened as the system gradually broke down during the sixties. Directives would sometimes get lost on the way down the governmental transmission belt, or they might be ignored here and there, or confused with apparently countermanding directives from competing agencies. The latter was a particularly common occurrence.)

Clearly, the political organization of Czechoslovakia from 1948 on had been divorced from the country's horizontal stratification patterns. The most frustrating and alienating aspect of the system, from the average citizen's point of view, was the almost total lack of communication upward through the ranks of the state bureaucracy, itself functioning as an effective buffer between rulers and ruled. The starkness of differentiation between these vertical strata tended to outweigh the subtler divisions along horizontal lines. Because the rigid vertical bifurcation of society assured the supremacy of political over social considerations, the groupings that developed within mass society were unable to aggregate their specific interests and translate them into demands upon the state for policy outputs.

Meanwhile, the effect of nationalization and collectivization was to "proletarianize" all individuals. All became employees, directly or indirectly, of the state. When the state in such circumstances is characterized by a monopolistic rule, downward-flowing administrative command networks, and a hierarchical managerial elite, the ultimate effect is the re-creation of a class society. In Czechoslovakia, as in all totally nationalized and collectivized East European countries, proletarian mass society came to be exploited, in a very real way, by the party and managerial elites. Postwar Czechoslovakia became

33. It is, of course, significant that one aspect of Czechoslovakia's repluralization was the tendency among these elites themselves to develop distinct group identities conscious of their own collective interests. 
a class society in which a relatively small power elite assumed dominant control over a much larger mass. Thus, crudely put, the vertical stratification of socialist Czechoslovakia approximates the "new class" formulation of Marxist critics sach as Trotsky, Djilas, Kuroń, and Modzelewski. ${ }^{34}$

In short, the picture which emerges is that of a neoclass structure complete with superordinate exploiters jealous of their power and infected with a class-consciousness of their own, and a great mass of subordinate "exploitees" who have little or no chance of influencing the power structure or ever penetrating the inscrutable stratum of the privileged few.

The fact that mass society became stratified (or restratified) under socialism-under the conditions as well of the bifurcated power structureintensified the potential for political conflict, because the central government could not satisfy the multiple interests of the various strata without the benefit of open channels of communication. In fact, it did not even know what was brewing down below. The more perceptive members of the nonelite strata became frustrated with their own political impotence, while the small number of their leaders who did recognize the problem were too weak to effect any fundamental change in the political superstructure. It is true that the economic reforms of the 1960 s had a genuine decentralizing impact on economic decisionmaking, but this in fact served to perpetuate, and even intensify, the primary vertical cleavage in society. A few more people entered the elite ranks, as plant managers and technocrats, but the division between those who had influence and those who had none persisted.

Directives continued to flow downward through the media of the mass organizations, with no corresponding channeling of influence upward. The press was not yet in a position to speak for the incipient interest groups, save for the increasingly defiant and constantly beleaguered organs of the Writers' Union. ${ }^{35}$ Nor could the Communist Party, riven with internal factions though it was, become an effective force for aggregating the interests of the various strata, for the party elite continued to guard their power monopoly jealously, and the predominant conservative forces managed to keep their opponents isolated one from the other. This situation lasted until late 1967.

In the meantime, a number of scholars had begun to probe into the matter of the political system and its relationship to social stratification. Mlynár, a high-ranking party member who headed an Academy team assigned to study

34. Those of us concerned with contemporary social theory are indebted to Ralf Dahrendorf for his brilliant argument refuting the classical Marxian assumption that property ownership alone is the basis of class relations in industrial society. See Dahrendorf, Class and Class Confict in Industrial Society (Stanford, 1959).

35. Literárni noziny (Prague) and Kultírny żivot (Bratislava) were particularly interesting in this light. See Dušan Hamšik, Writers Against Rulers (New York, 1971), for a discussion. 
possible modes of political reform, recognized the outlines of the problem and suggested a somewhat vague solution. He proposed the establishment of regularized, institutionalized channels for the functioning of interest groups. He believed that the incipient social groupings did indeed have specialized interests and should be allowed the means of aggregating them. He argued that the mass organizations, party and state institutions, must not be used only as transmission belts for directives sent downward: "The action must be reciprocal; there must be a flow of influence from the people generally to the state (and to the party)." ${ }^{36}$

Michal Lakatoš, a Slovak-born scholar of jurisprudence, agreed with Mlynár and took the argument one step further. He advocated the formation of autonomous organizations whose sole function would be the aggregation and articulation of group interests. These must be new organizations, because most of those already in existence did not serve this purpose. Lakatoš rejected the traditional argument that there were no significant differences of political interest within socialist society, referring disdainfully to this idea as the "theory of conflictlessness" (bezkonfliktnost), arguing that it was neither accurate nor desirable. In a series of articles appearing in 1965 and 1966, Lakatos developed his own theory that the driving force of progress within society is the confrontation of divergent interests, and not the artificial harmony which seemed on the surface to exist. Socialist ownership of the means of production had not brought about the end of divisions within society. On the contrary, in Czechoslovakia it had created divisions anew among individuals and interest groups (zaujmové skupiny). Differences of interest and the potential for conflict are natural in human relations: "Even a socialist society must consistently resolve its divisions by methods adequate to their character if a conflictual situation is to be avoided." 37 But because there were no available vehicles for the aggregation of interests, the individual at present is a "political unit isolated from his interest group." The only way to reconcile this problem of the atomized individual is to put him in direct touch with the proper institution and to allow that institution to function as a direct agent of its constituents' true interests, an organized go-between to link mass society with the party and state. ${ }^{38}$

Lakatoš suggested that interest groups could be formed along any of several possible lines, each including within it the possibility of subgroups: by relation to means of production (for example, groups for workers in the state

36. Zdeněk Mlynár̆, "Problems of Political Leadership and the New Economic Mechanism," World Marxist Review, 8 (December 1965): 81; emphasis in the original.

37. "K niektorým problemom štruktúry našej politickej śustavy" [On Some Problems in the Structure of Our Political System], Právny obzor, 48, no. 1 (1965): 28.

38. Ibid., p. 30. 
sector, for collective-farm workers, for artisans, and so forth); according to the division of labor (industrial workers, farmers, physical versus mental work) ; according to ethnic identity, territorial interests, or male-female divisions. ${ }^{39}$ Finally, he argued that the direct representation of people's interests could not be guaranteed within the existing institutional framework. Rather, it must be based on new institutions that themselves should be subject to truly free elections. ${ }^{40}$

The fundamental issue raised by Mlynáŕ and Lakatoš in 1965, and taken up by Sik and others as well, was the question of how the expression of divergent interests should be guaranteed and how they could be harmonized to the advantage of society. That there were legitimate social forces working to make these interests concrete was amply demonstrated in the studies of the Machonin team of sociologists, who documented the indisputable diversification of the social infrastructure in Czechoslovakia. These scholars were only a few years ahead of their time. The issue they raised permeated the politics of 1968 on all levels. As Vladimir V. Kusin has suggested, the secret to the real meaning of the Prague Spring was the revitalization of the political infrastructurethat is, society's stratification groupings. ${ }^{41}$ For in 1968 these groupings became aware of themselves as potentially autonomous parts of society, with separate and frequently conflicting, but not irreconcilable, interests. They were now changing, by virtue of their increasing self-awareness and heightened selfconfidence, from "quasi-groups" to genuine interest groups-and threatening to become what Dahrendorf has called "conflict groups." They demanded a share in the political power structure, and many felt they were on their way to achieving it. ${ }^{42}$

This more than anything else was what ultimately brought on the Warsaw Pact intervention, because the Russians and their hardline allies feared the implicit threat of the Czechoslovak groups to the stability of the Communist Party's rule. Soviet Marxists have been unable (or unwilling) to shake themselves loose from the utopian assumption that socialist society must and inevitably will be politically homogeneous and free of conflict. No doubt recalling the unhappy events of 1956 in Hungary, Czechoslovakia's allies reached a point in August 1968 at which they felt that the unchecked pluralism of the Czechs and Slovaks was a serious, and possibly permanent, deviation from

39. Ibid., pp. 30-33.

40. "Niektoré problemy socialistickej demokracie $z$ hladiska postavenia občana $v$ našej spoločnosti" [Some Problems of Socialist Democracy from the Viewpoint of the Position of the Citizen in Our Society], Prázny obzor, 49, no. 3 (1966): 217-18.

41. Kusin, Political Grouping, pp. 211-14 and passim.

42. Dahrendorf, Class and Class Conflict, pp. $179 \mathrm{ff}$. Dahrendorf distinguishes conflict groups from others by virtue of their interest in the political relations of domination and subjection. 
the socialist path. Not only did the Czechoslovak groups challenge the Communist Party's monopoly of power, but they threatened to institutionalize what to the Russians could only be seen as a "bourgeois" order, one based on conflicting political interests. This was intolerable-given Czechoslovakia's strategic position within the Soviet security system, the ovell-known sympathies many Czechs felt toward the West, and (not to be underestimated) the possible "spillover" effects the Czechoslovak reforms would have on the neighboring masses of East Germany, Poland, and even the USSR. Seen from this angle, the decision to intervene was not only rational but probably the only outcome that could have been expected.

Repluralization had only begun by the time of the intervention. The differentiated strata of the social infrastructure, formed out of the very fabric of "classless" socialist society, became aware of their own existence and determined to play a guiding role in the emerging new political system. As long as the old leadership had been in power, the incipient forces had remained submerged, unaware of their political potential and, in any event, atomized by their inability to communicate. With the downfall of Novotny and the accession of reform leadership, these social forces were released. With the help of the intellectuals, who saw the developing situation clearly, and the mass media, which gave the intellectuals and others a public forum, mass society awakened to the new circumstances. Interest groups formed, breaking the old artificial mass organizational structure, and the distant rumblings of opposition political parties grew constantly louder, seeming to threaten the return of a power challenge to the Communists. ${ }^{43}$ The eight months of reform were far too short a time for any stable patterns to solidify, and many persons were still seeking their proper identity when the invasion called a halt to the pluralizing momentum. ${ }^{44}$

43. A number of former Social Democrats pleaded with Communist leaders privately on several occasions to let them restore their party. The Communists steadfastly refused, and the would-be SD restorationists accepted Communist authority for the time being. One active SD sympathizer with whom I have subsequently spoken told me he believed it was only a matter of time before the SDP would have sprung back to life, with or without the Communists' blessing, and had it come back it would have attracted an enthusiastic mass following. Whether or not he was right, the Communists seemed to fear the prospect.

As far as the possibility of new parties was concerned, KAN was at times mentioned as one prospect. In a small village near Karlovy Vary, KAN activists worked out a joint program of public works together with the local Communist officials. But such a practical instance of KAN's activities was atypical. KAN was mainly concerned with more general and philosophical matters, such as freedom. Moreover, KAN's organization was very loose, its followers were ideologically diffuse, and it had no clear-cut political program.

44. As Golan and others have demonstrated, the reforms as such were not immediately ended with the occupation. Dubček and his colleagues remained in office for several 
Earlier in this article it was emphasized that the original pluralism of Czechs and Slovaks had developed around national, religious, and class bases. After 1945 two of these determinants were neutralized, and the third, nationalism, was temporarily suppressed in a wave of Czech chauvinism. The centralistic policies of the post-1948 period had only a transitory denationalizing impact, and probably an illusory one at that. Nationality persisted as a basis for political differentiation, as the formation of specifically Slovak interest groups in the sixties demonstrated. Notwithstanding its great significance, however, the Czech-Slovak division in itself does not begin to explain the entire complexity of the repluralization phenomenon.

Political pluralism, whatever its original form or its current manifestation, is embedded in the consciousness of Czechs and Slovaks. It is indeed normative, as we have stated earlier. The citizen expects that, under normal circumstances (not including Stalinist or Soviet-imposed forms of rule), an individual in a political society can identify with an organized group that represents his general interests and orientations. Because different persons naturally perceive politics in their own ways, furthermore, there must be a plurality of such organizations to accommodate everybody. It is this normative characteristic of pluralism that links the political nature of contemporary and interwar Czechoslovakia. During the Stalinist years and again since 1968, Soviet-imposed political regimes have forcefully prohibited the organized expression of pluralism, thereby exposing a minority subculture of authoritarianism and antipluralism. The events of 1968 , however, bore witness to the shallowness of this subculture.

The persistence of pluralistic political orientations has posed a thorny problem for the Communist leadership. The regime's utmost efforts at resocializing the masses in the 1950 s obviously failed. Since the 1960 s it should be abundantly clear that the repression of overt vehicles of pluralism, such as opposition parties and autonomous clubs, does not eradicate the basic problem, for the problem is an attitudinal one. "Socialist man," voluntarily committed to the communist ideal and willing to deny his own idiosyncratic whims for the interests of society as a whole, has not come into being. ${ }^{45}$ Patterns of outward

months into 1969, and many of the reforms continued to be implemented as well. But the question of interest groups, and certainly of opposition parties, was destined to become a dead issue after August 1968.

45. Edward Taborsky, Conformity Under Communism: A Study of Indoctrination Techniques, Annals of International A ffairs Pamphlet (Washington, D.C.: Public Affairs Press, 1958); Raymond A. Bauer, The Nerc Man in Soviet Psychology (Cambridge, Mass., 1952). The importance of the "new socialist man" image as developed in the Stalinist period is debatable as far as the specific traits of the original model are concerned, but the general characteristics of commitment and self-denying altruism are still relevant as ideals for all Communist movements. The goal, even couched in these general terms, is a very elusive one and may well be unattainably utopian. 
behavior compliance have masked an inner rejection of the monolithic system, both in theory and in practice. ${ }^{46}$ The government cannot count on the loyalty of its subjects, for it has not won their respect or established its moral authority over them. In the years since 1968, Czech and Slovak society has once more become artificially homogenized, its intrinsic pluralism constrained, as it could only be, by coercion. ${ }^{47}$

46. Paul, "Nationalism, Pluralism, and Schweikism." See chapter 6, entitled "Schweikism: The Behavior Patterns of an Oppressed Nation."

47. For a brief discussion of recent underground pluralist activities see the dispatch by Bruce A. Manuel, "Czech Nonviolent Resistance Simmers," Christian Science Monitor, May 4, 1973, as well as numerous dispatches in the Rome-based émigré paper Listy. 